University of Nebraska - Lincoln

DigitalCommons@University of Nebraska - Lincoln

$1-1-1992$

\title{
Kinetic Analysis of Competing Intramolecular and Intermolecular Polymerization Reactions
}

\author{
Hossein Noureddini \\ Department of Chemical Engineering, University of Nebraska-Lincoln, hnouredd@unlnotes.unl.edu \\ Delmar C. Timm \\ University of Nebraska-Lincoln, dtimm1@unl.edu
}

Follow this and additional works at: https://digitalcommons.unl.edu/chemengmolecular

Part of the Chemical Engineering Commons

Noureddini, Hossein and Timm, Delmar C., "Kinetic Analysis of Competing Intramolecular and Intermolecular Polymerization Reactions" (1992). Papers in Molecular Chemistry. 5.

https://digitalcommons.unl.edu/chemengmolecular/5

This Article is brought to you for free and open access by the Chemical and Biomolecular Engineering Research and Publications at DigitalCommons@University of Nebraska - Lincoln. It has been accepted for inclusion in Papers in Molecular Chemistry by an authorized administrator of DigitalCommons@University of Nebraska - Lincoln. 
H. Noureddini and D. C. Timm, Kinetic Analysis of Competing Intramolecular and Intermolecular Polymerization Reactions, Macromolecules; 1992; 25(6); 1725-1730.

Kinetic Analysis of Competing Intramolecular and Intermolecular Polymerization Reactions

\section{H. Noureddini and D. C. Timm}

Department of Chemical Engineering, University of Nebraska, Lincoln, Nebraska

Received August 21, 1990; Revised Manuscript Received December 8, 1991

Macromolecules; 1992; 25(6); 1725-1730.

Copyright (C) 1992 American Chemical Society.

The American Chemical Society allows the posting of only the title, abstract, tables, and figures from articles appearing in the Macromolecules.

This article is available at published online at:

http://pubs.acs.org/cgi-bin/archive.cgi/mamobx/1992/25/i06/pdf/ma00032a016.pdf

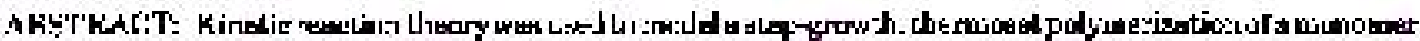

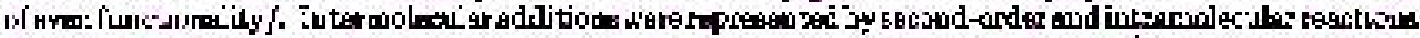

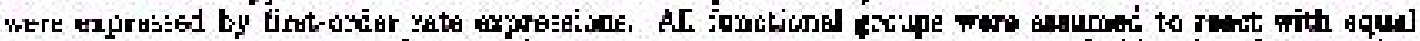

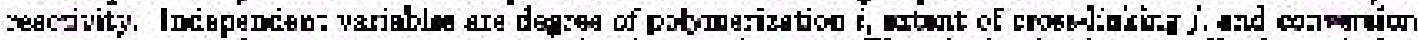

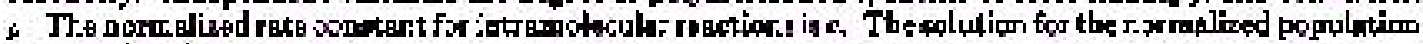
dersily distzibation is

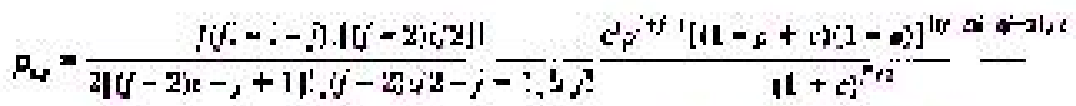

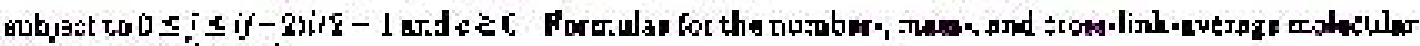
weighte were der:pec. 
H. Noureddini and D. C. Timm, Kinetic Analysis of Competing Intramolecular and Intermolecular Polymerization Reactions, Macromolecules; 1992; 25(6); 1725-1730.

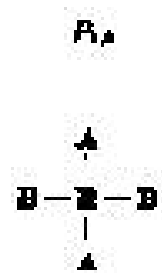

$\mathbf{R}_{\mathbf{1} 1}$

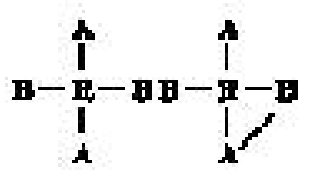

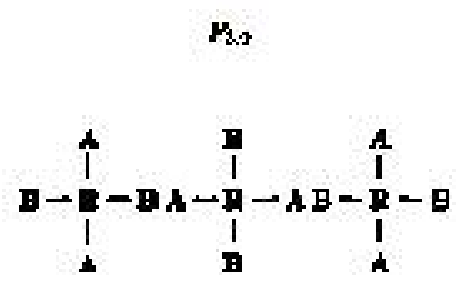

$\boldsymbol{F}, \mathbf{5}$

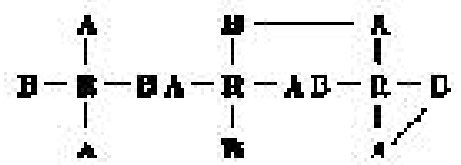

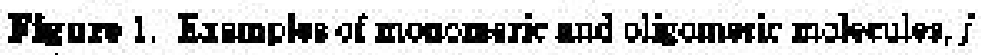
$=4$.

Copyright (C) 1992 American Chemical Society. 
H. Noureddini and D. C. Timm, Kinetic Analysis of Competing Intramolecular and Intermolecular Polymerization Reactions, Macromolecules; 1992; 25(6); 1725-1730.

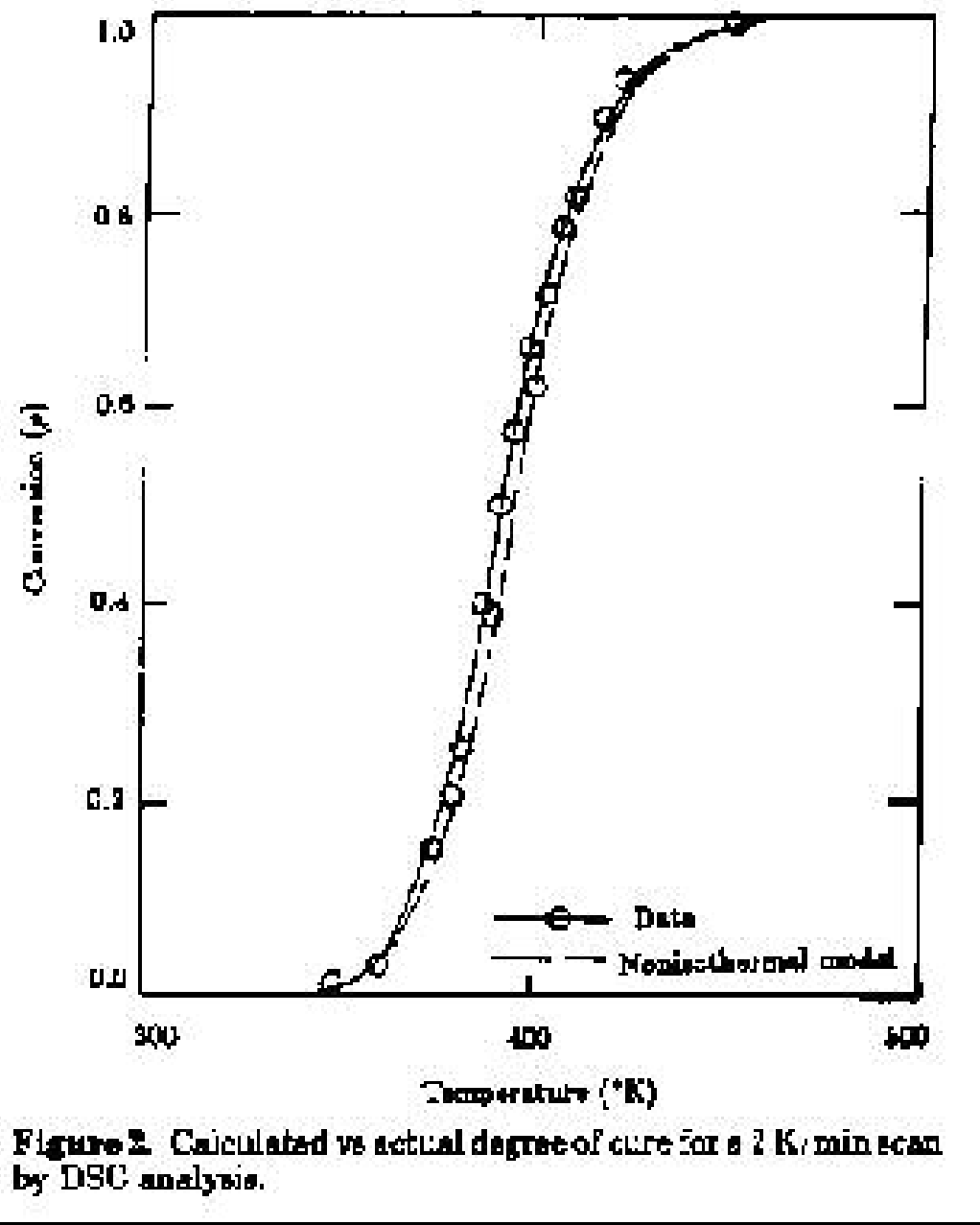

Copyright (c) 1992 American Chemical Society. 